\title{
Pengaruh Terpaan Media terhadap Partisipasi Politik dalam Pilkada DKI Jakarta 2017
}

\author{
Umar Halim, Kurnia Dyah Jauhari
}

\author{
Program Studi Ilmu Komunikasi, Universitas Pancasila \\ Jl. Srengseng Sawah, Jagakarsa, Jakarta Selatan, 12640 \\ Telp: (021) 7870451 \\ Email: umarhalim@univpancasila.ac.id; dyahij@gmail.com
}

\begin{abstract}
The political participation of the people is one of the indicators of democracy in every country. More and more citizens are involved the better, as it shows citizens following and understanding the political problems. This study uses the Stimulus-Response (S-R) theory. The purpose of this study is to examine whether the hypothesis that there is a positive and significant influence between media exposure to the level of political participation among the people of South Jakarta. This research used quantitative methods, with data collection techniques spreading questionnaires to the people of South Jakarta as many as 100 respondents from a population of 1,593,700 based on KPU data in 2016. The data analysis technique used is a regression. The results of this study showed that the stimulus-response theory tested through the hypothesis of media exposure provides a contribution (R Square: 27.6\%) to increase the level of political participation. The results also support that online media, social media, and chatting applications were more often used as a source of political information compared to printed newspaper, radio, and magazines. Another finding of the research is that the level of online and strategic participation is still very low. Strategic participation can be improved when Internet users are encouraged to have the ability to operate a wide range of applications and have political knowledge. The research has also contributed to the development of online participation concept through instrumental, informative, and strategic dimensions.
\end{abstract}

Keywords: Media Exposure, Political Participation, Online Participation, Offline Participation

\begin{abstract}
Abstrak
Partisipasi politik warga merupakan salah satu indikator berjalannya demokrasi di setiap negara. Semakin banyak warga yang terlibat semakin baik, karena menunjukkan warga negara mengikuti dan memahami masalah politik. Penelitian ini menggunakan teori Stimulus-Respon. Tujuan penelitian ini untuk menguji hipotesis bahwa terdapat pengaruh yang positif dan signifikan antara terpaan media terhadap tingkat partisipasi politik di kalangan masyarakat Jakarta Selatan. Penelitian ini menggunakan metode kuantitatif, dengan teknik pengumpulan data menyebarkan kuisioner kepada masyarakat Jakarta Selatan sebanyak 100 orang dari populasi 1.593 .700 berdasarkan data KPU tahun 2016. Teknik analisis data yang digunakan adalah regresi. Hasil penelitian ini menunjukkan bahwa teori Stimulus Respon teruji melalui hipotesis terpaan media memberikan kontribusi yang signifikan (R Square: 27,6\%) untuk menaikkan tingkat partisipasi politik. Kajian ini juga mendapatkan hasil bahwa media online, sosial media, dan aplikasi chatting lebih sering digunakan sebagai sumber informasi politik dibandingkan dengan media cetak, radio, dan majalah. Temuan lain dari penelitian adalah tingkat partipasi online yang bersifat instrumental dan strategis masih sangat rendah. Partisipasi strategis dapat ditingkatkan apabila para pengguna internet didorong untuk memiliki kemampuan mengoperasikan berbagai aplikasi dan memiliki wawasan politik. Penelitian ini telah memberikan kontribusi terhadap pengembangan konsep partisipasi online melalui dimensi instrumental, informatif, dan strategis.
\end{abstract}

Kata Kunci: Terpaan Media, Partisipasi Politik, Partisipasi Online, dan Partisipasi Offline

\section{Pendahuluan}

Demokrasi tidak akan berfungsi tanpa adanya partisipasi politik warga Negara
(Subiakto dan Ida, 2012: 72). Semakin banyak warga negara yang berpartisipasi maka semakin baik, karena menunjukkan bahwa 
warga negara mengikuti dan memahami masalah politik, serta terlibat dalam kegiatan dan prosesnya (Budiardjo, 2008: 369). Sebaliknya, jika tingkat partisipasi dari warga negara rendah diindikasikan kurang baik, karena dapat dianggap bahwa warga negara tidak memberikan perhatian terhadap masalah kenegaraan.

Partisipasi politik tidak hanya didefinisikan sebagai bentuk keterlibatan seseorang untuk "memilih atau tidak" dalam pemilihan. Lebih dari itu, partisipasi politik merupakan keterlibatan individu terhadap berbagai proses yang terjadi dalam peristiwa memilih pemimpin dan memengaruhi kebijakan politik. Beberapa kegiatan partisipasi bisa dilakukan dengan aktivitas menghadiri acara politik, bekerja untuk seorang kandidat calon, menyumbangkan uang untuk kampanye kandidat politik, menggunakan atribut untuk mendukung calon, serta mencoba untuk meyakinkan orang lain untuk memilih (Kenski \& Stroud, 2006: 175).

Partisipasi politik terbagi menjadi dua bentuk, partisipasi konvensional dan nonkonvensional (Almond dalam Damsar, 2010: 186). Partisipasi politik konvensional adalah suatu bentuk partisipasi politik yang normal dalam demokrasi modern, antara lain: pemberian suara atau voting, diskusi politik, kegiatan kampanye, membentuk dan bergabung dalam kelompok kepentingan, komunikasi individual dengan pejabat politik atau administratif. Sementara partisipasi politik non-konvensional adalah suatu bentuk partisipasi politik yang tidak lazim dilakukan dalam kondisi normal, bahkan dapat berupa kegiatan illegal, penuh kekerasan dan revolusioner, antara lain: pengajuan petisi, berdemonstrasi, konfrontasi, mogok, pengerusakan, pemboman, pembakaran, penculikan, pembunuhan, perang gerilya, revolusi, dan lain lain.

Perkembangan teknologi media baru telah mengubah pengalaman berpolitik masyarakat. Dengan internet para pengguna dapat mecari informasi politik dan berdiskusi dengan kawan (Akmal dan Salman, 2015: 93) mengomentari tulisan orang, memberikan opini dan member dukungan melalui media sosial. Pergeseran keterlibatan politik di atas mendorong para peneliti mengkaji partisipasi secara daring (online) seperti dilakukan oleh Jung, Kim dan Zúñiga (2011), Muntean (2015), serta Kim dan Chen (2016).

Partisipasi online merupakan kegiatan politik melalui pemanfaatan media baru, misalnya: mengikuti petisi online, mengikuti informasi politik secara online, memberikan komentar di media sosial, membuat opini atau tulisan politik, dan meneruskan berita politik yang sifatnya memengaruhi orang lain (Cohen dan Kahne, 2011: 6)

Yang \& DeHart(2016) yang meneliti 4.556 mahasiswa di Amerika menguji partisipasi politik online melalui aktivitas menulis kepada politisi secara online, membuat kontribusi kampanye secara online, berlangganan daftar politik, mendaftar menjadi relawan kampanye melalui online, mengirim pesan politik melalui email, dan menulis surat/berita kepada editor koran media online.

Cohen dan Kahne (2011: 6) meyakini partisipasi secara daring dapat memberikan pengaruh yang besar karena masyarakat, politisi dan kandidat dari partai politik secara 
langsung dapat saling berinteraksi dengan berbagai konten baik berupa gambar maupun tulisan dalam blog. Jung, Kim dan Zúñiga (2011: 414) mendiskripsikan bentuk partisipasi politik online pada berbagai aktivitas, yaitu: mengumpulkan informasi politik dari artikel online, mengirim email ke kandidat atau partai politik, mengunjungi website kandidat politik, serta menyumbangkan uang untuk seorang calon atau partai politik secara daring.

Kim dan Chen (2016) mengukur partisipasi politik secara online dengan aktivitas mencari informasi lebih tentang kandidat politik, membagikan foto, video, atau audio berkaitan dengan kampanye atau pemilu, meneruskan (forward) komentar orang lain atau menuliskannya kepada orang lain, meneruskan postingan audio atau video kepada orang lain; serta berlangganan atau menerima informasi politik.

Salman dan Saad (2015) di Malaysia mengukur partisipasi online dengan aktivitas memberikan komentar kepada editor melalui email, memberikan komentar di media online, komentar di blog atau artikel yang diunggah, terlibat dalam diskusi grup, dan mengunggah serta mengunduh video sebagai bentuk protes.

Tingkat partisipasi politik baik offline maupun online dalam beberapa literatur akan tinggi atas kontribusi terpaan media (media exposure). Potter (2012:19) menjelaskan bahwa "exposure" adalah istilah yang sering disinonimkan dengan "attention". Sementara dalam kajian efek media massa istilah "media exposure" kerap disebut sebagai terpaan media. Media exposure dalam kajian Vreese, CH dan Hajo, B (2006) berkontribusi terhadap meningkatnya pengetahuan dan partisipasi politik masyarakat di Denmark dan Belanda.

Selain itu, dalam bentuk online, Lee, Chen, dan Chan (2016) mendapatkan luaran bahwa gerakan demonstrasi Umbrella Movement di Hongkong didorong oleh terpaan media sosial. Studi lain dari Kim dan Chen (2016) juga menunjukkan hasil yang sama dimana terpaan media berupa penggunaan blog dan SNS berpengaruh terhadap partisipasi politik secara online pada masyarakat Amerika dalam pemilihan presiden 2008.

Penelitian Jung, Kim dan Zúñiga (2011: 414) yang mengkaji tentang pengaruh new media terhadap partisipasi politik dengan menggunakan model O-S-R-O-R (OrientasiStimulus-Penalaran-Orientasi-Response) efek komunikasi, menghasilkan gagasan bahwa pengetahuan politik dan politic efficacy menjadi mediator yang signifikan. Selain itu, hasil penelitian menggambarkan bahwa internet berpengaruh besar terhadap partisipasi politik.

Muntean (2015) telah menguji pengaruh penggunaan sosial media terhadap partisipasi politik kepada 130 pemilih pemula di Rumania. Hasil penelitian tersebut mendapatkan bahwa penggunaan media sosial untuk tujuan mengakses berita politik mengakuisisi secara signifikan terkait dengan partisipasi politik online, tapi tidak dengan partisipasi politik offline.

Penelitian ini menggunakan teori stimulus respon (SR). Teori SR menguraikan bahwa masyarakat rentan terpengaruh terhadap pesan-pesan komunikasi massa yang dianggap memiliki kekuatan besar (Severin \& Tankard, 2008: 146-147). Teori ini bertanya tentang apakah kualitas manusia, khususnya kualitas 
psikologi, datang dari stimulus pesan media dan respon audiens (Miller, 2015: 251). Miller (2015: 252) juga menambahkan bahwa teori SR menjelaskan manusia belajar dengan diberi imbalan atau hukuman ketika mereka menanggapi rangsangan tertentu. Pandangan Stuart Hall pun menegaskan bahwa manusia memang memiliki pemaknaan pesan bergantung pada latar belakang budaya dan pengalaman hidup khalayak itu sendiri. Varibel stimulus dalam penelitian ini berupa terpaan media, sementara sebagai variabel respon adalah partisipasi politik.

Terpaan media diukur dengan frekuensi menonton televisi, membaca majalah atau surat kabar, dan mendengarkan radio (Rakhmat, 2011: 65), sementara Rosengren dalam Rakhmat (2011: 66) menguji terpaan media dengan dimensi melihat jumlah waktu dan jenis isi media. Ardianto, Komala dan Karlinah (2015: 168) berpandangan bahwa terpaan media berusaha mencari data tentang penggunaan media dari jenis media, frekuensi maupun durasi penggunaan. Muntean (2015), Brown dan Wilkes (2014) juga mengukur terpaan media dengan frekuensi penggunaan media seperti Koran, Radio dan Televisi, Facebook dan Twitter. Berbeda dengan Vreese dan Hajo (2006) yang menguji terpaan media pada masyarakat Denmark dan Belanda hanya dengan konten media.

Konsep Digital divide digunakan sebagai alat ukur dalam menyusun indikator partisipasi online dalam membahas tingkat partisipasi online. Partisipasi politik secara daring akan membutuhkan kemampuan (skill) para penggunanya, karena menurut Servon (2002) untuk menggunakan ICT individu akan menghadapi tiga rintangan, yaitu: akses kepada sistem (antara individu dan teknologi); mengenal teknologi informasi (IT literacy); serta konten yang sesuai dan berguna untuk masyarakat.

Mossberger, Tolbert dan Stasnbury (2003), van Dijk (2005; 2006), serta Van Deursen dan van Dijk (2009) juga telah menguji variabel kemampuan dalam mengkaji kesenjangan dalam menggunakan internet. Para peneliti mendapatkan hasil bahwa tingkat kemahiran berpengaruh terhadap tingkat kekerapan dan penggunaan yang berkualitas. Mossberger dkk. (2003) membagi variabel kemahiran dengan dua sub-dimensi, yaitu: 1) kemampuan secara teknis yang bertujuan untuk mengkaji kemahiran dalam mengendalikan hardware dan software. 2) kemampuan informasi bermaksud untuk mengidentifikasi berbagai informasi yang dapat memberikan solusi terhadap suatu masalah, atau memenuhi kebutuhan informasi dan secara efektif dapat menggunakan sumber informasi.

Sementara itu, Van Deursen dan Van Dijk (2009) menguji kemahiran menjadi tiga dimensi, yaitu: kemahiran instrumental, informatif dan strategis. Kemampuan intrumental bermaksud untuk mengetahui kemahiran individu dalam menggunakan material software dan hardware. Kemampuan informatif bermaksud menguji kemampuan untuk mencari, memilih dan memperoses informasi melalui komputer dan berbagai sumber yang tersedia, sedangkan kemampuan strategis diuji untuk mengetahu kemampuan individu dalam menggunakan komputer dan berbagai sumber dengan tujuan tertentu dan tujuan secara umum untuk memperbaiki kondisi masyarakat. 
Pemilihan kepala daerah di DKI Jakarta, Indonesia, di tahun 2017 mendapat sorotan dari berbagai media, tidak hanya media lokal dan nasional, bahkan internasional, seperti Parlemen Belanda mendorong menteri luar negerinya, Bert Koenders, untuk mengajukan keprihatinan mereka atas dihukumnya Ahok, dan mengangkat isu tersebut ke Uni Eropa (www.bbc.com, 10 Mei 2017).

Sorotan pemberitaan tersebut dilatarbelakangi ucapan Basuki Tjahaya Purnama "Ahok" sebagai calon petahana yang dianggap menyinggung umat Islam. Pernyataan Ahok tentang "surat AlMaidah-51" menimbulkan respon negatif dari masyarakat sehingga demontrasi terjadi beberapa kali di Jakarta yang melibatkan banyak elemen dengan tuntutan Ahok harus diadili.

Perseteruan ucapan 'Ahok' dalam konteks Pilkada DKI tidak akan mendapatkan perhatian dari masyarakat tanpa adanya peran media. Cangara (2009: 118) berpendapat karena media menjadi salah satu sumber informasi politik, masyarakat jadi mengetahui segala kebijakan dan proses politik yang terjadi. Pemberitaan media tersebut memberikan asumsi bahwa media menjadi faktor yang mendorong masyarakat untuk terlibat dalam proses politik Pilkada DKI 2017.

Pertanyaannya kemudian dalam konteks Pilkada DKI Jakarta adalah apakah pemberitaan media berpengaruh pada tingkat partisipasi politik warga? Apakah masyarakat juga telah memanfaatkan media untuk mencari informasi Pilkada DKI? Dan sejauhmana tingkat partisipasi politik offline dan online masyarakat?
Penelitian ini menguji hipotesis terdapat pengaruh yang positif dan signifikan antara terpaan media terhadap tingkat partisipasi politik masyarakat Jakarta Selatan pada Pilkada DKI 2017. Terpaan media dilihat dari jenis media, frekuensi penggunaan media, jenis konten dan konten berita sebagai sumber informasi. Tingkat partisipasi politik masyarakat Jakarta Selatan ditinjau dari partisipasi offline dan online.

\section{Metode Penelitian}

Penelitian ini menggunakan metode kuantitatif dengan populasi masyarakat di Kota Jakarta Selatan berjumlah 1.593.700 berdasarkan data KPU tahun 2016. Peneliti menyebarkan kuisioner pada tanggal 2-10 Januari 2017 kepada 100 responden sebagai sampel dengan teknik pengambilan sampel stratified random sampling dengan alasan pengambilan sampel dari populasi dengan memperhatikan adanya strata dalam populasi tersebut, yaitu dari setiap strata ada anggota populasi yang dipilih menjadi sampel. Responden yang ditemui berusia $>17$ tahun. Variabel yang diuji dalam penelitian ini adalah terpaan media dan tingkat partisipasi politik.

Konsep penelitian ini yaitu terpaan media menurut Ardianto dkk (2015), Muntean (2015), Brown dkk (2014), dan Vreese dkk (2006) dan partisipasi politik menurut Salman dkk (2015), Kenski dkk (2006), Akmal dkk (2015), Jung dkk (2011), Kim dkk (2016), Cohen dkk (2011), dan Yang dkk (2016). Variabel penelitian ini, yaitu terpaan media online dan offline. Terpaan media adalah seberapa besar responden diterpa pemberitaan Pemilihan Kepala 
Daerah DKI Jakarta 2017 pada putaran pertama. Varibel ini dianalisis dengan empat dimensi, yaitu: jenis media, frekuensi penggunaan, jenis konten pemberitaan, dan konten pemberitaan. Dimensi jenis media diukur dengan jenis media yang digunakan sebagai sumber informasi tentang Pilkada DKI 2017. Jenis media yang menjadi pilihan adalah koran, majalah, radio, TV, media online, sosial media, dan aplikasi chatting.

Dimensi Frekuensi dimaksud untuk menganalisis seberapa sering para responden menggunakan koran, majalah, radio, TV, media online, sosial media, dan aplikasi chatting untuk mencari informasi tentang Pilkada DKI. Sementara dimensi jenis konten media diuji untuk melihat tingkat konsumsi jenis konten yang mengandung isu Pilkada DKI. Jenis konten yang diuji adalah meme (gambar/video lucu), video atau vlog pendukung calon, tautan berita, opini tokoh atau ulama dan iklan kandidat Gubernur dan Wakil Gubernur.

Dimensi konten pemberitaan Pilkada DKI yang diuji antara lain: Informasi dari KPU, visi misi kandidat, kampanye, pelanggaran kampanye, dana kampanye, elektabilitas kandidat, dukungan masyarakat, penolakan masyarakat, campur tangan elit politik dan kasus yang menimpa kandidat calon.

Variabel partisipasi politik dalam penelitian ini didefinisikan sebagai keterlibatan responden pada Pilkada DKI 2017 melalui berbagai bentuk aktivitas. Variabel ini diukur dengan dua dimensi, yaitu partisipasi offline dan partisipasi online. Dimensi partisipasi offline dilihat dari indikator kegiatan para responden untuk ikut serta secara aktif dan langsung dalam dinamika politik Pilkada DKI, sementara dimensi partisipasi online indikatornya berupa berbagai aktivitas politik Pilkada DKI Jakarta para responden.

Partisipasi politik offline diukur dengan 11 item dari sub-dimensi: menyalurkan aspirasi, menjadi relawan, mengikuti kegiatan/kampanye, berdiskusi, mengikuti perkembangan politik melalui media cetak, dan memengaruhi orang lain untuk memilih salah satu calon. Partisipasi politik online juga diukur dengan 11 item pernyataan dari 3 (tiga) sub-dimensi kemahiran internet yang dipaparkan oleh Van Deursen dan Van Dijk (2009), yaitu: Instrumental (3 item), Informatif (5 item) dan Strategis (3 item).

Instrumental bermaksud untuk menguji aktivitas daring yang sifatnya terlibat tanpa harus memiliki kemampuan mengoperasikan aplikasi yang sulit dan tidak harus memiliki pemahaman politik, seperti: tergabung grup atau gerakan mendukung atau menolak kandidat, mengajak orang bergabung grup, dan meneruskan informasi (teks, video, gambar atau link). Sub-dimensi informatif bertujuan untuk mengukur aktivitas yang membutuhkan pengetahuan dan penguasaan terhadap berbagai sumber dalam internet dan aktivitas yang dapat menambah informasi politik pengguna, seperti: mengikuti berbagai berita, memberikan respon berupa "like", memberikan komentar, mendiskusikan, dan memperhatikan diskusi politik. Terakhir, partipasi strategis bermaksud untuk menguraikan aktivitas pengguna yang memerlukan kemampuan menguasasi 
berbagai aplikasi, penggunaannya strategis dan berdampak kepada orang lain. Subdimensi strategis diukur dengan aktivitas: membuat tulisan atau gambar, membuat petisi dan mengikuti petisi.

Teknik analisis data yang digunakan dalam penelitian ini yaitu uji regresi untuk menguji hipotesis terdapat pengaruh yang positif dan signifikan antara terpaan media tentang Pilkada DKI Jakarta terhadap tingkat partisipasi politik di masyarakat Jakarta Selatan.

\section{Hasil Penelitian dan Pembahasan}

Penelitian ini telah melakukan survei terhadap 100 responden di Jakarta Selatan. Dari keseluruhan responden $49 \%$ berjenis kelamin laki-laki, dan 51\% responden perempuan. Dari aspek pekerjaan, responden dengan status Pelajar atau Mahasiswa sebanyak $21 \%$, bekerja sebagai pegawai negeri sebanyak $10 \%$, bekerja sebagai pegawai swasta sebanyak $29 \%$, sebagai wiraswasta sebanyak 7\%. Purna karya atau pensiun sebanyak atau $6 \%$, dan pekerjaan lain-lain sebanyak $27 \%$ responden.

\section{Hasil Analisis Data}

\section{Terpaan Media}

Tabel 1 mendeskripsikan analisis jenis media yang digunakan responden sebagai sumber informasi Pilkada DKI 2017. Hasil dalam Tabel 1 menunjukkan bahwa jenis media yang dipilih untuk menjadi sumber informasi politik DKI Jakarta adalah televisi $(\mathrm{M}=2.98)$, setelah itu media online $(\mathrm{M}=2.92)$, media sosial $(\mathrm{M}=2.36)$, aplikasi chatting $(\mathrm{M}=2.33)$, dan media cetak $(\mathrm{M}=2.26)$. Hasil ini juga menunjukkan bahwa sedikit
Tabel 1. Penggunaan Jenis Media Sebagai Sumber Informasi Pilkada DKI 2017

\begin{tabular}{lcc}
\hline & Mean* & $\begin{array}{c}\text { Standard } \\
\text { Deviation }\end{array}$ \\
\hline Media Cetak & 2.26 & .89 \\
Majalah & 1.57 & .75 \\
Radio & 1.66 & .89 \\
Televisi & 2.98 & .83 \\
Media online & 2.92 & .86 \\
Sosial Media & 2.36 & .95 \\
Aplikasi & 2.33 & .88 \\
Chatting & & \\
\hline
\end{tabular}

*Mean $=0$ (tidak setuju) sampai 4 (sangat setuju) Sumber: Hasil olah data peneliti (2018)

responden yang masih menggunakan radio dan majalah untuk mencari isu Pilkada DKI.

Tabel 2 menguraikan hasil frekuensi penggunaan media online untuk mencari informasi Pilkada DKI 2017. Hasil dalam tabel 2 menunjukkan bahwa televisi dan media online $(\mathrm{M}=3.00)$ sebagai sumber yang sering digunakan oleh para responden untuk mencari informasi politik Pilkada DKI Jakarta. Media lainnya yang digunakan adalah media sosial $(\mathrm{M}=2.30)$, aplikasi chatting $\quad(\mathrm{M}=2.29)$ dan media cetak $(M=2.24)$. Sementara radio dan majalah menjadi sumber yang rendah digunakan

Tabel 2. Frekuensi Penggunaan Media sebagai Sumber Informasi Pilkada DKI 2017

\begin{tabular}{lcc}
\hline & Mean* & $\begin{array}{c}\text { Standard } \\
\text { Deviation }\end{array}$ \\
\hline Media Cetak & 2.24 & .96 \\
Majalah & 1.63 & .77 \\
Radio & 1.71 & .88 \\
Televisi & 3.00 & .79 \\
Media online & 3.00 & .86 \\
Sosial Media & 2.30 & .94 \\
Aplikasi & 2.29 & .93 \\
Chatting & & \\
\hline
\end{tabular}

*Mean $=0$ (tidak setuju) sampai 4 (sangat setuju) Sumber: Hasil olah data peneliti (2018) 
Tabel 3. Jenis Konten Berita sebagai Sumber Informasi Pilkada DKI 2017

\begin{tabular}{lcc}
\hline & Mean* & $\begin{array}{c}\text { Standard } \\
\text { Deviation }\end{array}$ \\
\hline $\begin{array}{l}\text { Meme (Gambar/ } \\
\text { Video Lucu) }\end{array}$ & 2.28 & .90 \\
$\begin{array}{l}\text { Video/Vlog Pendukung } \\
\text { Calon }\end{array}$ & 2.00 & .82 \\
Link (Tautan) Berita & 2.63 & .88 \\
$\begin{array}{l}\text { Opini Tokoh/Ulama } \\
\text { Iklan Kandidat }\end{array}$ & 2.34 & .89 \\
Gubernur DKI & 2.57 & .95 \\
\hline
\end{tabular}

*Mean $=0$ (tidak setuju) sampai 4 (sangat setuju)

Sumber: Hasil olah data peneliti (2018)

untuk mencari informasi Pilkada DKI.

Dimensi selanjutnya adalah hasil uji jenis konten berita yang sering dilihat oleh para responden. Pada tabel 3 didapatkan bahwa tautan (link) berita $(\mathrm{M}=2.63)$ merupakan jenis konten berita yang sering dilihat oleh para responden. Jenis konten selanjutnya adalah iklan kandidat gubernur $(\mathrm{M}=2.57)$, opini tokoh $(\mathrm{M}=2.34)$, konten meme $(\mathrm{M}=2.28)$ dan video/vlog pendukung calon $(\mathrm{M}=2.00)$.

Terakhir, pada tabel 4 diuraikan hasil tentang konten pemberitaan Pilkada DKI 2017. Hasil uji analisis menunjukkan bahwa "kasus yang menyeret kandidat" $(\mathrm{M}=2.91)$ dan isu "penolakan masyarakat terhadap kandidat" $(\mathrm{M}=2.82)$ adalah konten pemberitaan yang paling tinggi dicari oleh para responden. Isu selanjutnya berkaitan dengan elektabilitas kandidat $(\mathrm{M}=2.75)$, isu dukungan masyarakat terhadap kandidat $(\mathrm{M}=2.72)$, isu kampanye $(\mathrm{M}=2.64)$ dan isu tentang campur tangan elit politik ( $\mathrm{M}=2.58)$. Hasil lainnya mendapatkan bahwa isu tentang dana kampanye dan informasi pelaksanaan dari KPU jarang dicari oleh para responden.

\section{Partisipasi Politik}

Pada sub-bab ini akan menguraikan temuan tentang partipasi politik secara offline dan online. Data pada tabel 5 (Partisipasi Politik Offline) menunjukkan bahwa berdiskusi mengenai isu Pilkada bersama teman, rekan kerja, atau keluarga merupakan aktivitas yang sering dilakukan oleh

Tabel 4. Konten Pemberitaan tentang Pilkada DKI 2017

\begin{tabular}{clcc}
\hline No & \multicolumn{1}{c}{ Konten Berita } & Mean* & $\begin{array}{c}\text { Standard } \\
\text { Deviation }\end{array}$ \\
\hline 1 & Informasi terkait pelaksanaan Pilkada DKI dari KPU & 1.83 & .69 \\
2 & Visi dan misi atau janji kandidat & 2.39 & .75 \\
3 & Kampanye kandidat Gubernur DKI & 2.64 & .76 \\
4 & Penyimpangan/pelanggaran kampanye & 2.49 & .78 \\
5 & Dana kampanye Pilkada DKI & 1.90 & .79 \\
6 & Elektabilitas Kandidat Gubernur DKI & 2.75 & .84 \\
7 & Dukungan masyarakat terhadap kandidat & 2.72 & .82 \\
8 & Penolakan masyarakat terhadap kandidat & 2.82 & .92 \\
& Campur tangan elit politik dalam Pilkada & 2.58 & .99 \\
9 & Kasus yang menyeret kandidat & 2.91 & .91 \\
\hline
\end{tabular}

*Mean $=0$ (tidak setuju) sampai 4 (sangat setuju)

Sumber: Hasil olah data peneliti (2018) 
Tabel 4. Partisipasi Politik Offline

\begin{tabular}{|c|c|c|c|}
\hline No & Konten Berita & Mean* & $\begin{array}{l}\text { Standard } \\
\text { Deviation }\end{array}$ \\
\hline 1 & Menyalurkan Aspirasi dengan aksi turun ke Jalan & 1.70 & .78 \\
\hline 2 & Menyalurkan Aspirasi dengan menghubungi langsung kandidat & 2.01 & .88 \\
\hline 3 & $\begin{array}{l}\text { Menjadi relawan atau tim sukses yang membantu proses jalannya } \\
\text { kampanye }\end{array}$ & 2.19 & .88 \\
\hline 4 & $\begin{array}{l}\text { Menjadi relawan atau tim sukses yang memberikan dukungan } \\
\text { materil untuk mendukung kandidat (uang, KTP, dll) }\end{array}$ & 2.22 & .87 \\
\hline 5 & $\begin{array}{l}\text { Menerima pemberian berupa materil dari kandidat Gubernur } \\
\text { DKI/Partai }\end{array}$ & 2.01 & .91 \\
\hline 6 & $\begin{array}{l}\text { Berdiskusi mengenai isu Pilkada bersama teman, rekan } \\
\text { kerja/keluarga }\end{array}$ & 2.74 & .85 \\
\hline 7 & Berdebat mengenai isu Pilkada bersama teman, rekan kerja/keluarga & 2.50 & .79 \\
\hline 8 & Membaca berbagai informasi mengenai isu Pilkada di media cetak & 2.29 & .88 \\
\hline 9 & $\begin{array}{l}\text { Mencari informasi mengenai isu pilkada melalui berbagai media } \\
\text { cetak }\end{array}$ & 2.07 & .89 \\
\hline 10 & Memengaruhi seseorang untuk memilih seorang kandidat tertentu & 2.10 & .82 \\
\hline 11 & $\begin{array}{l}\text { Memengaruhi seseorang untuk tidak memilih seorang kandidat } \\
\text { tertentu }\end{array}$ & 1.90 & .88 \\
\hline
\end{tabular}

*Mean $=0$ (tidak setuju) sampai 4 (sangat setuju)

Sumber: Hasil olah data peneliti (2018)

mayoritas responden $(M=2.74)$. Selain itu, berdebat juga sering dilakukan $(\mathrm{M}=2.50)$, kemudian membaca berbagai informasi di media cetak $(M=2.29)$, dan menjadi relawan tim sukses $(M=2.22)$. Sementara itu, aktivitas memengaruhi seseorang untuk tidak memilih dan menyalurkan aspirasi dengan turun ke jalan menjadi aktivitas yang sangat rendah dilakukan oleh para responden.

Kajian ini juga telah menguji partisipasi politik online. Data pada tabel 6 menunjukkan bahwa "Memperhatikan diskusi (silent reader) mengenai isu Pilkada di sosmed/Aplikasi Chatting" menjadi aktivitas politik yang sering dilakukan oleh mayoritas responden $(M=2.76)$. Selanjutnya aktivitas yang sering dilakukan oleh para responden adalah memberikan respon berupa like di media online atau sosial media
$(\mathrm{M}=2.58)$, mengikuti berbagai berita Pilkada DKI $(\mathrm{M}=2.57)$, dan memberikan komentar/ pendapat baik melalui media online maupun sosial media (2.53). Sementara aktivitas tergabung dalam grup mendukung atau menolak salah satu kandidat dan mengajak seseorang bergabung dalam grup hanya dilakukan oleh sebagian kecil responden. Aktivitas yang memerlukan keterampilan khusus dalam penggunaan internet seperti membuat tulisan/gambar dan membuat petisi online juga hanya dilakukan sebagian kecil responden.

\section{Hasil Uji Hipotesis}

Penelitian ini menguji hipotesis, terdapat pengaruh yang positif dan signifikan antara terpaan media tentang Pilkada DKI Jakarta terhadap tingkat partisipasi politik di masyarakat Jakarta Selatan dengan analisis regresi. 
Tabel 6. Partisipasi Politik Online

\begin{tabular}{clcc}
\hline No & \multicolumn{1}{c}{ Konten Berita } & Mean* & $\begin{array}{c}\text { Standard } \\
\text { Deviation }\end{array}$ \\
\hline 1 & $\begin{array}{l}\text { Tergabung dalam grup/gerakan mendukung atau menolak salah satu } \\
\text { kandidat }\end{array}$ & 1.70 & .62 \\
2 & $\begin{array}{l}\text { Mengajak seseorang untuk tergabung dalam group/gerakan } \\
\text { mendukung atau menolak salah satu kandidat calon }\end{array}$ & 1.78 & .58 \\
3 & $\begin{array}{l}\text { Meneruskan (copy paste) berbagai informasi berupa teks/video/ } \\
\text { gambar terkait isu Pilkada DKI ke sosial media/aplikasi chatting }\end{array}$ & 2.25 & .81 \\
4 & $\begin{array}{l}\text { Mengikuti berbagai berita Pilkada DKI di Media Online atau Sosial/ } \\
\text { Aplikasi Chatting }\end{array}$ & 2.57 & .85 \\
5 & $\begin{array}{l}\text { Memberikan respon berupa like terhadap isu Pilkada DKI yang ada di media } \\
\text { Online atau Informasi yang dibagikan orang lain di media sosial }\end{array}$ & 2.58 & .77 \\
6 & $\begin{array}{l}\text { Memberikan komentar/pendapat di media online/sosial media/ } \\
\text { aplikasi chatting }\end{array}$ & 2.53 & .76 \\
7 & $\begin{array}{l}\text { Membahas/mendiskusikan isu Pilkada di sosmed/Aplikasi Chatting } \\
\text { yang dimiliki }\end{array}$ & 2.45 & .81 \\
8 & $\begin{array}{l}\text { Memperhatikan diskusi (silent reader) mengenai isu Pilkada di } \\
\text { sosmed/Aplikasi Chatting }\end{array}$ & 2.76 & .83 \\
9 & $\begin{array}{l}\text { Membuat tulisan atau gambar tentang isu Pilkada DKI kemudian } \\
\text { membagikannya ke sosial media/aplikasi chatting }\end{array}$ & 1.97 & .76 \\
10 & $\begin{array}{l}\text { Membuat petisi online } \\
11\end{array}$ Mengikuti/sign petisi online & 1.90 & .78 \\
\hline
\end{tabular}

*Mean $=0$ (tidak setuju) sampai 4 (sangat setuju)

Sumber: Hasil olah data peneliti (2018)

Berdasarkan hasil analisis data melalui teknik regresi dengan bantuan program SPSS diketahui bahwa terpaan media berpengaruh terhadap partisipasi politik (sig. 0,000). Ini dapat dibuktikan dari hasil uji hipotesis melalui t-test sebagai berikut:

Ho $=$ Koefesien regresi tidak signifikan $(\mathrm{t}$ hitung $<\mathrm{t}$ tabel $) /($ Sig. $>0.05)$
Koefesien regresi signifikan ( $\mathrm{t}$ hitung $>\mathrm{t}$ tabel)/(Sig. $<0,05)$

Diketahui bahwa signifikansi koefesien regresi adalah 0,000 yang artinya Ho ditolak atau thitung $=6,073>$ dari pada nilai $\mathrm{t}$ tabel (nilai kritis $\mathrm{t})=1,988(\mathrm{df}=97)($ tabel 8$)$. Besarnya pengaruh adalah 27,6\% (Adjusted $R$ Square), artinya variabel terpaan media
Tabel 7. Hasil Uji Regresi Tabel Model Summary

\begin{tabular}{ccccc}
\hline Model & $\mathrm{R}$ & $\mathrm{R}$ & $\begin{array}{c}\text { Adjusted R } \\
\text { Square }\end{array}$ & $\begin{array}{c}\text { Std. Error } \\
\text { of the } \\
\text { Estimate }\end{array}$ \\
\hline 1 & $.525^{\mathrm{a}}$ & .276 & .268 & 7.76780 \\
\hline
\end{tabular}

a. Predictors: (Constant), Media Exposure

Sumber: Hasil Uji Statistik Menggunakan IBM SPSS 25,2018
Tabel 8. Hasil Uji Regresi Tabel ANOVA

\begin{tabular}{llccccc}
\hline \multicolumn{1}{c}{ Model } & $\begin{array}{c}\text { Sum of } \\
\text { Squares }\end{array}$ & df & $\begin{array}{c}\text { Mean } \\
\text { Square }\end{array}$ & F & Sig. \\
\hline 1 & Regression & 2225.655 & 1 & 2225.655 & 36.886 & $.000^{\mathrm{b}}$ \\
& Residual & 5852.850 & 97 & 60.339 & & \\
\multicolumn{1}{c}{ Total } & 8078.505 & 98 & & & \\
\hline a. Dependent Variable: Par & & & \\
b. Predictors: (Constant), Medial \\
\multicolumn{5}{l}{ Sumber: Hasil Uji Statistik Menggunakan IBM SPSS 25, 2018 }
\end{tabular}


Tabel 9. Hasil Uji Regresi Koefisien

\begin{tabular}{cccccc}
\hline & \multicolumn{2}{c}{$\begin{array}{c}\text { Unstandardized } \\
\text { Coefficients }\end{array}$} & $\begin{array}{c}\text { Standardized } \\
\text { Coefficients }\end{array}$ & & \\
& $\mathrm{B}$ & Std. Error & Beta & & Sig. \\
& \multicolumn{1}{c}{ Model } & & & & \\
\hline Medial & .390 & .064 & .525 & 6.073 & .000 \\
\hline
\end{tabular}

a. Dependent Variable: Par

Sumber: Hasil Uji Statistik Menggunakan IBM SPSS 25, 2018

mampu memprediksikan partsipasi politik sebesar 27,6\%) (tabel 7), sedangkan sisanya sebanyak $72,4 \%$ dijelaskan oleh sebabsebab lainnya.

Berdasarkan hasil analisis data melalui teknik regresi dengan bantuan program SPSS diketahui bahwa terpaan media berpengaruh terhadap partisipasi politik (sig. 0,000). Ini dapat dibuktikan dari hasil uji hipotesis melalui t-test sebagai berikut:

Ho $=$ Koefesien regresi tidak signifikan $(\mathrm{t}$ hitung $<$ t tabel $) /($ Sig. $>0.05)$

$\mathrm{H} 1=$ Koefesien regresi signifikan ( $\mathrm{t}$ hitung

$>$ t tabel $) /($ Sig. $<0,05)$

Diketahui bahwa signifikansi koefesien regresi adalah 0,000 yang artinya Ho ditolak atau $t$ hitung $=6,073>$ dari pada nilai $t$ tabel (nilai kritis $\mathrm{t})=1,988(\mathrm{df}=97)($ tabel 8). Besarnya pengaruh adalah 27,6\% (Adjusted $R$ Square), artinya variabel terpaan media mampu memprediksikan partsipasi politik sebesar 27,6\%) (tabel 7), sedangkan sisanya sebanyak $72,4 \%$ dijelaskan oleh sebabsebab lainnya.

Pada tabel 8 dapat dilihat hasil uji ANOVA atau $\mathrm{F}$ test dimana didapat Fhitung 36,886 dengan tingkat signifikansi 0,000, karena probabilitas $(0,000)$ merupakan nilai yang lebih kecil dari 0,05 , maka model regresi dapat digunakan untuk memprediksi pengaruh terpaan berita pilkada DKI terhadap partisipasi politik dengan menggunakan rumus persamaan regresi linear $\mathrm{Y}=\mathrm{a}+\mathrm{bX}$.

Hasil uji hipotesis menunjukkan penelitian ini mendukung teori SR bahwa terpaan media yang menjadi stimulus memengaruhi tingkat partisipasi politik sebagai respon. Beberapa temuan penting juga telah didapatkan sesuai dengan konsep terpaan media Ardianto dkk (2015), Muntean (2015), Brown dkk (2014), dan Vreese dkk (2006), dan konsep partisipasi politik dari para peneliti seperti Salman dkk (2015), Kenski dkk (2006), Akmal dkk (2015), Jung dkk (2011), Kim dkk (2016), Cohen dkk (2011), dan Yang dkk (2016).

Berdasarkan hasil analisis data diketahui bahwa selain televisi, saat ini internet telah menjadi platform baru untuk dijadikan sumber informasi politik masyarakat. Hal tersebut ditandai dengan tingkat frekuensi penggunaan media online, media sosial dan aplikasi chatting yang tinggi sebagai sumber informasi politik dibandingkan dengan media cetak, radio dan majalah.

Pemilihan media baru sebagai sumber informasi politik tentu tidak terlepas dari 
meningkatnya penetrasi pengguna internet di Indonesia yang telah mencapai 53.2\% pengguna di tahun 2019 (internetworldstats. com, 27/6/2019). Selain itu, APJII (2017) mendapatkan hasil bahwa $36.94 \%$ pengguna internet di Indonesia telah menjadikan internet sebagai sumber informasi politik.

Temuan penelitian ini sedikit berbeda dengan kajian Muntean (2015) yang mendapatkan hasil media sosial menjadi sumber yang paling tinggi dalam partisipasi online. Penggunaan media online lebih tinggi dibandingkan dengan media sosial. Tingginya tingkat penggunaan media online dalam penelitian ini secara konsisten juga ditunjukkan melalui hasil analisis jenis konten yang digunakan oleh para responden, dimana membuka tautan (link) berita adalah jenis konten yang paling tinggi dibuka.

Hasil penelitian Muntean (2015) yang menyatakan bahwa penggunaan media sosial lebih tinggi dibandingkan media online dapat diasumsikan bahwa tautan berita yang dibuka oleh para pengguna internet berasal dari media sosial. Media sosial memiliki banyak ragam dan fungsi sehingga setiap penggunanya dapat melakukan berbagai aktivitas seperti berdiskusi, menulis opini dan peristiwa politik, serta membagi tautan berita, gambar dan video. Hal ini menjadi salah satu faktor yang mendorong para peneliti hanya mengkaji partisipasi online di media sosial, seperti Yang dan DeHart (2016), Rainie, Smith, Schlozman, Brady, dan Verba (2012) meneliti partisipasi politik online di media sosial Facebook dan Twitter; serta Akmal dan Salman (2015) menguji partisipasi online dengan semua media sosial.

Terkait hasil analisis konten pemberitaan relevan dengan situasi politik Pilkada DKI 2017, dimana kandidat gubernur petahana Basuki Tjahaya Purnama "Ahok" ketika sebelum masa kampanye dalam sambutannya di Kepulauan Seribu menyinggung umat Islam dengan kalimat "jangan mau dibohongi dengan surat AlMaidah 51." Sehingga konten berita yang sering dicari masyarakat adalah pemberitaan tentang kasus yang menyeret kandidat dan penolakan masyarakat terhadap kandidat.

Hasil lainnya adalah berkaitan dengan partisipasi politik. Temuan penelitian tentang partisipasi politik offline telah mendukung penelitian Salman dan Saad (2015) yang mendapatkan hasil bahwa berdiskusi tentang isu politik terkini adalah aktivitas yang kerap dilakukan. Sementara untuk partisipasi online aktivitas memperhatikan diskusi politik di sosial media adalah aktivitas yang paling sering dilakukan oleh responden.

Bentuk partisipasi online yang sering dilakukan oleh para responden berdasarkan hasil penelitian ini adalah aktivitas yang bersifat informatif, sementara aktivitas yang bersifat instrumental dan strategis jarang dilakukan. Tingkat partisipasi instrumental rendah disebabkan indikator yang dijadikan ukuran berupa aktivitas yang cenderung sudah memiliki pilihan politik. Sementara itu, tingkat partisipasi strategis rendah disebabkan dengan kebutuhan kemampuan pengguna untuk mengoperasikan aplikasi, serta memiliki pengetahuan politik. Hal ini selaras dengan Van Dijk (2005) yang menyatakan bahwa untuk memanfaatkan 
teknologi yang lebih berkualitas, berselancar dan memiliki motovasi saja tidak cukup tanpa adanya kemampuan menggunakan teknologi.

Secara umum hasil penelitian ini mendukung hipotesis bahwa terpaan media berkontribusi terhadap tingkat partisipasi politik seperti yang diuji oleh Yang dan DeHart (2016) pada 4.606 mahasiswa di Amerika Serikat, dan Kenski dan Stroud (2006, h.186) yang meneliti media exposure dengan partisipasi politik di Amerika Serikat.

\section{Simpulan}

Hasil penelitian ini menunjukkan bahwa terpaan media yang diuji dengan jenis media, frekuensi penggunaan media, jenis konten berita, dan konten berita politik Pilkada DKI Jakarta secara signifikan memengaruhi tingkat partisipasi politik pada Pilkada DKI Jakarta. Hasil penguadratan $\mathrm{R}$ dalam uji Regresi menjelaskan kontribusi terpaan berita Pilkada DKI terhadap partisipasi politik sebesar $27,6 \%$, sisanya sebesar 72 , $4 \%$ dipengaruhi oleh faktor-faktor lain seperti kebutuhan psikologis/sosial, pengetahuan politik, kesengajaan/ketidaksengajaan, dan rasional/emosional.

Penelitian ini juga menemukan bahwa televisi dan media online menjadi sumber yang paling tinggi yang digunakan untuk mencari informasi politik DKI Jakarta. Jenis konten yang sering dibuka oleh para responden adalah tautan berita online, dan konten berita yang sering dibuka adalah penolakan masyarakat terhadap kandidat.

Temuan lainnya yaitu tingkat partsipasi politik offline yang paling sering dilakukan para responden adalah berdiskusi mengenai isu Pilkada bersama teman, rekan kerja/ keluarga, sementara partisipasi politik online yang paling tinggi dilakukan oleh para responden adalah memperhatikan diskusi (silent reader) mengenai isu Pilkada di sosial media / aplikasi chatting.

Secara umum, penelitian ini mendukung teori SR yang telah diuji melalui variabel terpaan media Pilkada DKI Jakarta 2017, dan tingkat pertisipasi politik warga Jakarta Selatan.

Rekomendasi penelitian selanjutnya adalah: 1) menguji variabel lain yang dapat berkontribusi terhadap meningkatnya partisipasi politik masyarakat, seperti pengetahuan politik dan kebutuhan psikologis/sosial; 2) mendisain bangunan dimensi partsipasi politik offlinekonvensional dan non-konvensional, dengan partsipasi politik secara daring; 3) menguji partisipasi secara daring dengan mengukur dimensi instrumental, informatif dan strategis, serta membandingkan partisipasi politik pemuda pedesaan dan perkotaan.

\section{Daftar Pustaka}

Asosiasi Penyelenggara Jasa Internet Indonesia. (2017). Infografis: Penetrasi dan Prilaku Penggunaan Internet Indonesia. By (https://web.kominfo.go.id/).

Ardianto, E., Komala dan Karlinah (2015). Komunikasi Massa: Suatu Pengantar. Bandung: Simbiosa Rekatama Media.

bbc.com. (2017). Parlemen Belanda Angkat Upaya Pembebasan Ahok dalam Debat. Retrieved from https://www.bbc.com/ indonesia/dunia-39872700

Budiardjo, Miriam (2008). Dasar-dasar Ilmu Politik. Jakarta: PT. Gramedia Pustaka Utama. 
Brown, CC. \& Wilkes, R (2014). Media exposure and the engaged citizen: How the media shape political participation. The Social Science Journal, 52 (3), 408-421.

Cangara, Hafied (2009). Komunikasi Politik: Konsep, Teori, dan Strategi. Jakarta: Rajawali Pers.

Cohen, J Cathy \& Kahne, Joseph. (2011). Participatory Politics New Media and Youth Political Action. Mills College Chicago.

Damsar (2010). Pengantar Sosiologi Politik. Jakarta: Kencana Prenada Media Group.

Internet Word Stats. (2019). Internet Usage in Asia. Retrived from https:// internetworldstats.com/stats3.htm.

Jung, N., Kim, Y. \& Gil de Zúñiga, H. (2011). The Mediating Role of Knowledge and Efficacy in the Effects of Communication on Political Participation. Mass Communication and Society, 14 (4), 407-430.

Kenski, K. and Stroud, N.J. (2006) Connections Between Internet Use and Political Efficacy, Knowledge, and Participation. Journal of Broadcasting \& Electronic Media, 50 (2), (2006) 173-192.

Kim, Yonghwan \& Chen, Hsuan-Ting (2016). Social media and online political participation: The mediating role of exposure to cross-cutting and likeminded perspectives. Telematics and Informatics, Vol: 33, pp. 320-330.

Lee, Francis L.F; Chen, Hsuan-Ting dan Chan, Michael (2016). Sosial media use and university students' participation in a large-scale protest campaign: The case of Hong Kong's Umbrella Movement. University of Hong Kong.

Miller, K. (2015). Communication Theories: Perspectives, Proceesses, and Contexts. 2nd edition. New York: McGraw-Hill.
Muntean, Alina. (2015). The Impact of Sosial Media Use on Political Participation (Unpublish thesis). Aarhus University, Denmark.

Mossberger, K., Tolebert, J.C. \& Stansbury, M. (2003). Virtual Inequality: Beyond the Digital Divide. Washington, DC: Goergetown University Press.

Potter, WJ (2012). Media Effect. California: Sage Publications.

Rainie, L., Smith, A., Schlozman, KL., Brady, H \& Verba, S. (2012). Social Media and Political Engagement. Washington., D.C: Pew Research Center's Internet and American Life Project.

Rakhmat, J. (2011). Psikologi Komunikasi. Bandung: PT. Rosdakarya.

Salman, Ali \& Saad, Suhana. (2015). Online Political Participation: A Study of Youth Usage of New Media. Mediterranean Journal of Social Science, MCSER, Vol $6 \mathrm{No} 4 \mathrm{~S}$.

Akmal, A \& Salman, Ali. (2015). Partsipasi Politik Belia Secara "Online" Melalui Ruang Demokrasi Maklumat Media Baru. Malaysian Journal of Communication, 31 (1), 81-100.

Servon, L. (2002). Bridging the Digital Divide: Technology, Community, and Public Policy. Oxford: Blackwell Publishers.

Severin, WJ \& Tankard, JW. (2008). Teori Komunikasi: Sejarah, Metode, dan Terpaan di Dalam Media Massa (Terj). Edisi ke5. Cet ke-3. Jakarta: Kencana Prenada Media Grup.

Subiakto, Henry \& Ida, Rachmah (2012). Komunikasi Politik, Media, \& Demokrasi. Jakarta: Kencana.

Umar Halim \& Samsudin A. Rahim. (2011). Penglibatan digital: Akses dan penggunaan E-agama dalam kalangan generasi muda Muslim. Jurnal Komunikasi Malaysia, 27 (2), 121-135. 
Van Deursen, A. J.A.M. \& Van Dijk, J.A.G.M. (2009). Using the Internet: Skill Related Problems in Users' Online Behavior. Interacting with Computer 21: 393-402.

Van Dijk, J.A.G.M. (2006). Digital Divide Research, Achievements and Shortcomings. POETICS 34: 221-235.

Van Dijk, J.A.G.M. (2005). The Deepening Divide: Inequality in the Information Society. London: Sage Publication.

Vreese, Claes H. de and Boomgaarden, Hajo. (2006). News, Political Knowledge and
Participation: The Differential Effects of News Media Exposure on Political Knowledge and Participation. Acta Politica, Vol. 41 (4), pp. 317-341.

Yang, Hongwei "Chris" \& DeHart, Jean L. (2016). Social Media Use and Online Political Participation Among College Students During the US Election 2012. Social Media + Society, Vol: 2(1), pp 1-18.

www.bbc.com. Parlemen Belanda Angkat Upaya Pembebasan Ahok dalam Debat. 10 Mei 2017. 